\title{
River Flow Conditions and Dynamic State Analysis of Pahang River
}

\author{
${ }^{1}$ Muhamad Barzani Gasim, ${ }^{2}$ M.E. Toriman, ${ }^{1}$ Mushrifah Idris, ${ }^{1}$ Pan Ian Lun, \\ ${ }^{2}$ M.K.A. Kamarudin, ${ }^{2}$ A.A. Nor Azlina, ${ }^{3}$ Mazlin Mokhtar and ${ }^{2}$ S.A. Sharifah Mastura \\ ${ }^{1}$ School of Environmental and Natural Resources Sciences, Faculty of Sciences and Technology, \\ ${ }^{2}$ School of Social, Development and Environmental Studies, Faculty of Social Sciences and Humanities, \\ ${ }^{3}$ Institute for Environment and Development, \\ National University of Malaysia, 43600, Bangi Selangor, Malaysia
}

Received 2012-09-06, Revised 2012-09-17; Accepted 2013-02-14

\begin{abstract}
Pahang River (Sg. Pahang) is the longest river in Peninsular Malaysia. Flood is a common event in Pahang River Basin during wet season which triggered by monsoon season. The hydrodynamic study of Pahang River should be well understood especially when it is a target of northeast monsoon which influenced the Pahang River Basin every year (from November to March). 17 river cross section stations were selected and used to measure its drainage capacity, hydraulic parameters and estimation of flow discharge. Long term (1980 to 2009) variation of hydrologic data series comprised of river flow, river stage and rainfall data were analyzed based on the Department of Irrigation and Drainage (DID) Malaysia record. Monthly rainfall was recorded from Sg. Yap, Temerloh and Lubuk Paku Rainfall Stations. Two hydrologic sampling trips had been carried out; first sampling on January 2010 and second sampling on February 2010. The study indicates that velocity and river flow measurement during first sampling ranged from 0.308 to $0.582 \mathrm{~m} \mathrm{sec}^{-1}$ and 153.282 to $439.684 \mathrm{~m} \mathrm{sec}^{3}$. Meanwhile, during second sampling, the velocity and river flow ranged from 0.217 to 0.484 and 52.071 to $304.485 \mathrm{~m}^{3} \mathrm{sec}^{-1}$, respectively. Floods were occurred annually at Pahang River especially during northeast monsoon, these events are expected to be stimulated by the inconsistent condition of width and depth along Pahang River which finally create sedimentation and meandering characteristic.
\end{abstract}

Keywords: Pahang River, Mean Flow, Monsoon Season, Extreme Rainfall, River Dynamic, Flood

\section{INTRODUCTION}

The river hydrodynamic is a basic study which is important to understand the river dynamic state especially when climate factors such as raining season and dry season as among the main factors to cause greatly impact to hydrodynamic change of a river. Therefore, the river flow might change in a drastic form when human activities such as land use changes and rapid development taking along the river bank or within the river basin (Walter and Tullos, 2010). In this case, we considered extreme weathers have given great impact to hydrodynamic change of Pahang River. For example, extreme rainfall which is triggered by northeast monsoon has caused overflowing of the Pahang River, while the drought or dry season which has caused to the lowest flow of the Pahang River. The Intergovernmental Panel on Climate Change, IPCC (2001) defines an extreme weather event "as an event that is rare within its statistical reference distribution at a particular place". The extremely high or low rainfall or precipitation leading to flood or drought, is an example of a substantial weather risk (Fu and Wen, 1999; Zin and Jemain, 2010; Pal and Al-Tabbaa, 2010). According to John (1987), monsoon rain and winds are the end result of heating patterns produced by the sun and the of heating patterns produced

Corresponding Author: Kamarudin, M.K.A., School of Social, Development and Environmental Studies,

Faculty of Social Sciences and Humanities, National University of Malaysia, 43600, Bangi Selangor, Malaysia 
distribution of land and ocean. Monsoons are characterized by their seasonality, geographical preference and strength. In Malaysia, especially in Pahang River Basin has received highly total rainfall on November or December, whereas almost 40 percent of total annual rainfall (Suhaila et al., 2010). Extreme rainfall that triggered by northeast monsoon from November until March yearly is the main factor that results to higher river flow and contributes to serious flooding events at Pahang River Basin in Pahang State (DID, 2005; 2006; 2009) as well as in its neighboring state. The increased of river flow that caused by the large volume of rainfall would probably change the size of the river which involved the changes in width and depth of the river due to river bank erosion (Andersson et al., 2006; Kamarudin et al., 2009; Jung et al., 2011; Hoyle et al., 2012). According to Camporeale et al. (2007) and Kale and Hire (2004), the river revolution is driven by fluid dynamic and morph dynamic processes, which cause lateral bank erosion and the continuous migration of meanders. Chow et al. (1988) added that flow propagation in natural rivers is complicated by several factors: junctions and tributaries, variations in cross section, variations in resistance as a function both flow depth and of location along the river, inundated areas and meandering of the river. The river hydrodynamic could directly affect the river pattern and caused to the changes of river morphology (Schwendel et al., 2012). Meandering rivers are dynamical systems far from equilibrium driven by complex linear and nonlinear processes (Camporeale et al., 2005). Indeed, river meanders are one of the most common patterns in fluvial morphology (Chitale, 1970; Allen, 1982; Howard, 1992). Unsteady flow in natural meandering rivers in wide flood plains is complicated by large differences in resistance and cross-sectional geometries of the river and the flood plain (Chow et al., 1988; Jaafar et al., 2010a). This study is highlight the dynamic stage and drainage capacity of Pahang River through the river cross-section study and to identify the effect of the extreme rainfall mainly caused by northeast monsoon for the river hydrodynamic system. Secondary data is important as reference and supplementary information especially for those researches involved long term variation observation. According to Yan (1987) in hydrological procedure no.4 of DID Malaysia had mentioned that, some not-so-quality secondary data may due to errors in data collection, errors in data analysis, not-functioning of water-level recorders and inaccurate gauging measurements also attribute to the poor quality of peak discharge records of a stream flow station. Furthermore, some of the hydrologic stations that were established prior to 1960 were operated by stick gauges before being upgraded to the automatic recorder system. The manual recording way has caused some reading had missed and not recorded and underestimation had occurred. Zin and Jemain (2010) ever mentioned that the problem of unavailability of a large dataset is unavoidable especially in developing countries and this situation is more critical for extreme events analysis. This issue had been highlighted as one of the key uncertainties in the IPCC 4th Assessment Report. In the report, it is stated that climate data coverage remains limited in some regions with marked scarcity in developing countries, thus making analyzing and monitoring changes in extreme events, including extreme frequency and intensity of precipitation more difficult than for climatic averages as longer data time series of higher spatial and temporal resolutions are required. However, in many countries, mostly because of maintenance costs, the present trend is a diminution of in-situ networks (Vorosmarty et al., 1999). Moreover, large regions in the world are still poorly gauged due to accessibility difficulties (Augusto et al., 2009). For this study the problem could be solved by using rating curve method and compared with other hydrologic gauging stations nearby.

\section{MATERIALS AND METHODS}

Pahang River is the longest river in Peninsular Malaysia with length $459 \mathrm{~km}$ and its upstream located at the Main Range of Titiwangsa (Lun et al., 2010). Pahang River is the main channel which located in Pahang River Basin and responsible to drain the water from this basin during wet season especially flood event (Lun et al., 2011; Jaafar et al., 2010b). It divided into Tembeling River (Sg. Tembeling) and Jelai River (Sg. Jelai) and both meet at a confluence at Kuala Tembeling which located $300 \mathrm{~km}$ away from the estuary of Pahang River (Kuala Pahang). The river meanders through townships such as Jerantut, Temerloh, Maran, Bera, Pekan and lastly flowing into the South China Sea located at the East Coastal of Peninsular Malaysia. 17 hydrologic sampling stations (one station at the estuary of Jelai River, one station at estuary of Tembeling River and 15 stations along Pahang River until downstream site) have been selected and two hydrologic samplings (January 2010-wet season and February 2010-dry season) have been carried out (Fig. 1). Hydrologic sampling involved measuring of river cross-section (width and depth) and velocity of the river flow for each sampling station.

The traditional measuring method which using the gauging staff and measuring tape could not be applied for Pahang River which having the river width more than $100 \mathrm{~m}$ and the depth could be reached more than $10 \mathrm{~m}$. 


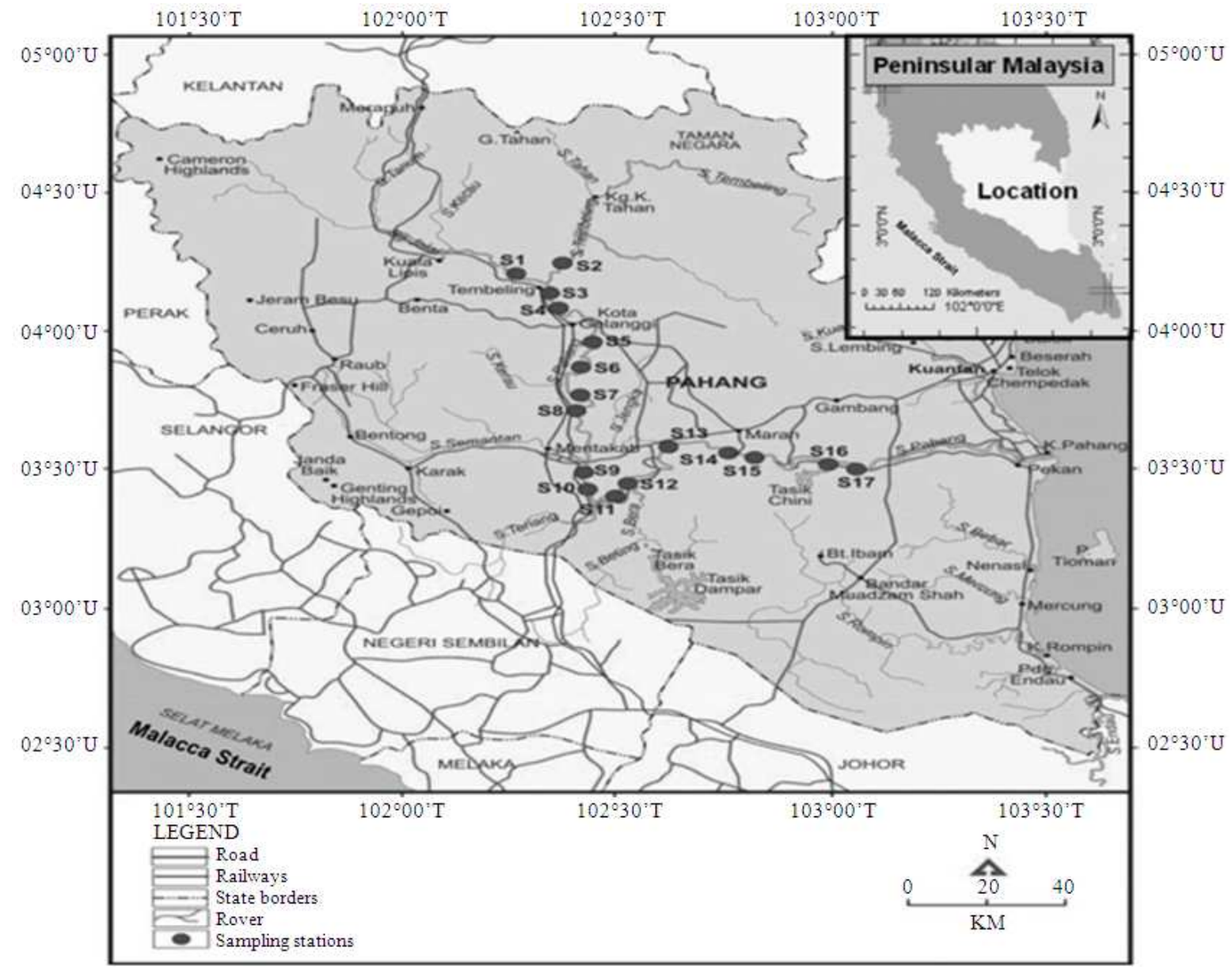

Fig. 1. Location of the study area

Range Finder (Bushnell Scout 1000) and handheld sonar (HawkEye) had been used for these measuring purposes instead of the limited length of gauging staff and measuring tape. Measuring of flow velocity by used Current meter (Global Water model FP 201). The river cross-section was measured to determine the river flow of each hydrologic sampling station with the simple equation, area of the river cross-section multiply with velocity of the water. The simple calculation of river flow is as below:

$$
\mathrm{Q}=\mathrm{A} \times \mathrm{V}
$$

Where:

$\mathrm{Q}=$ Discharge, cumec, $\mathrm{m}^{3} \mathrm{sec}^{-1}$

$\mathrm{A}=$ Area of river cross-section, $\sum(\mathrm{i} \mathrm{x} d), \mathrm{m}^{2}$

$\mathrm{V}=$ Velocity, $\mathrm{m}^{2} / \mathrm{s}$

\section{RESULTS}

Two hydrologic samplings have been conducted; first sampling was carried out on January of 2010 which was represented end of raining season and the second sampling was conducted on February of 2010 represented for dry season. In the year 2010, the total monthly rainfall on the February range between 5 to $80 \mathrm{~mm}$, this range was based on five rainfall stations that located in surrounded study in the catchment area (Fig. 2). The velocity of Pahang River during first sampling ranged from 0.308 to $0.582 \mathrm{~m} \mathrm{sec}^{-1}$ and second sampling was from 0.217 to $0.484 \mathrm{~m} \mathrm{sec}^{-1}$ (Fig. 3). The trend of velocity from station 1 to station 17 during first sampling is slightly increased but slightly decreased for the second sampling; indeed, 
Leopold (1953) has identified a tendency increase of velocity for further downstream.

During first sampling, the river flow ranged from 153.282 to $439.684 \mathrm{~m}^{3} \mathrm{sec}^{-1}$, but its drop during the second sampling with lower flow range from 52.071 to $304.485 \mathrm{~m}^{3} \mathrm{sec}^{-1}$ due to a dry spell (Fig. 4). Although river flows from Station-1 to Station-17 were unsteady but the trend for the both samplings were show increased. The unsteady condition of river flow was expected due to the inconsistent condition of width and depth along the Pahang River that finally bearing growth to meandering shape (sinuosity pattern along the river course).

Pahang River possessed of inconsistent of river width along its river course. In general, the trend of river width of Pahang River was increased from upstream to downstream (Fig. 5), only at the existing meander (curve-shape area) decreased its width. For example, the width of station14 (meander part) was only130 m compared to the previous (441 m). On the other hand, the existing condition of the narrowest river usually was the deepest area. For example, station 14 with a narrow river banks $(130 \mathrm{~m})$ but associated to the deepest depth $(14.858 \mathrm{~m})$. The result of 17 sampling stations showed that, the river depth was inconsistent from upstream to downstream (Fig. 6). But flowing downstream, the depth of the river has decreased or became shallower, increased their width or became wider. The inconsistent of river width and depth were caused by the Pahang River possessed for meandering characteristic which showing the sinuosity along it river course. Indeed, river meanders are one of the most common patterns in fluvial morphology (Chitale, 1970; Allen, 1982; Howard, 1992; Wallis et al., 2012; Toriman et al., 2012).

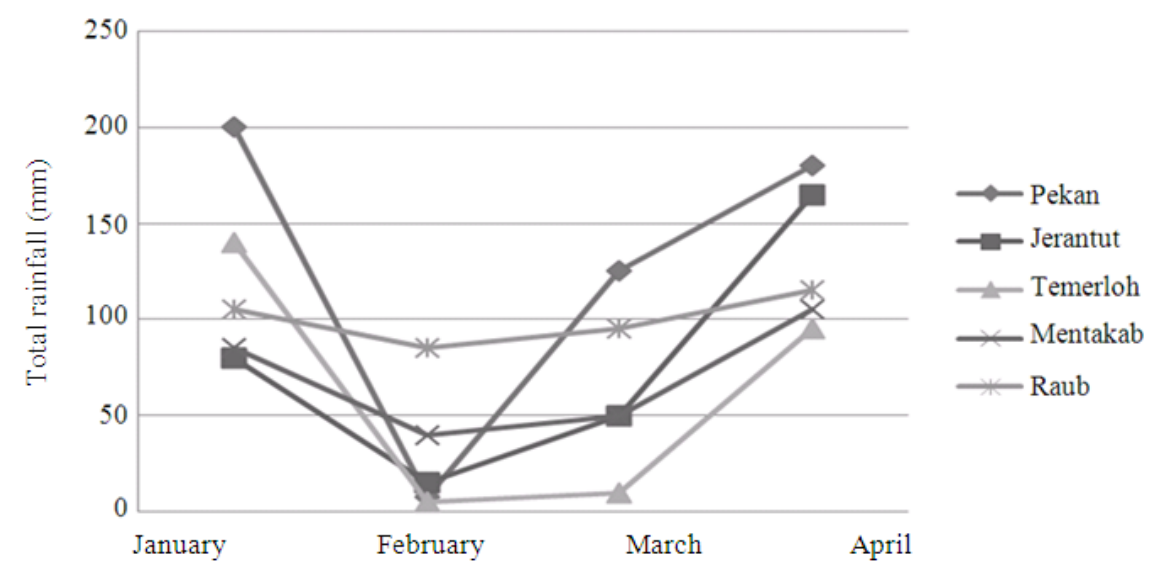

Fig. 2. The trend of total monthly rainfall 2010 from five rainfall stations

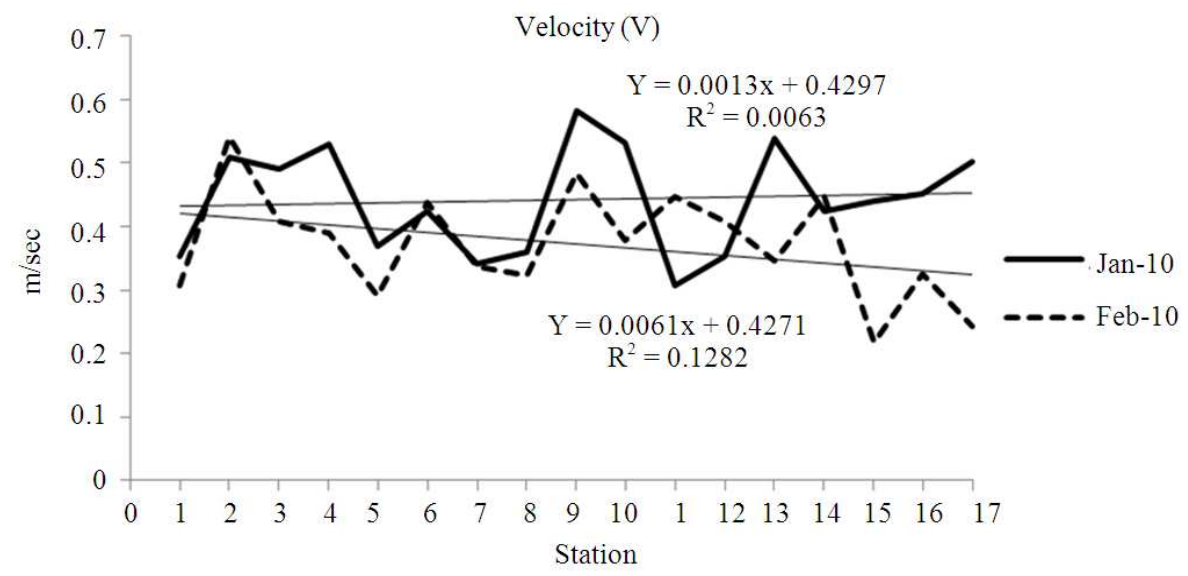

Fig. 3. The velocities of 17 hydrologic stations for two samplings 
Muhamad Barzani Gasim et al. / American Journal of Applied Sciences, 10 (1): 42-57, 2013

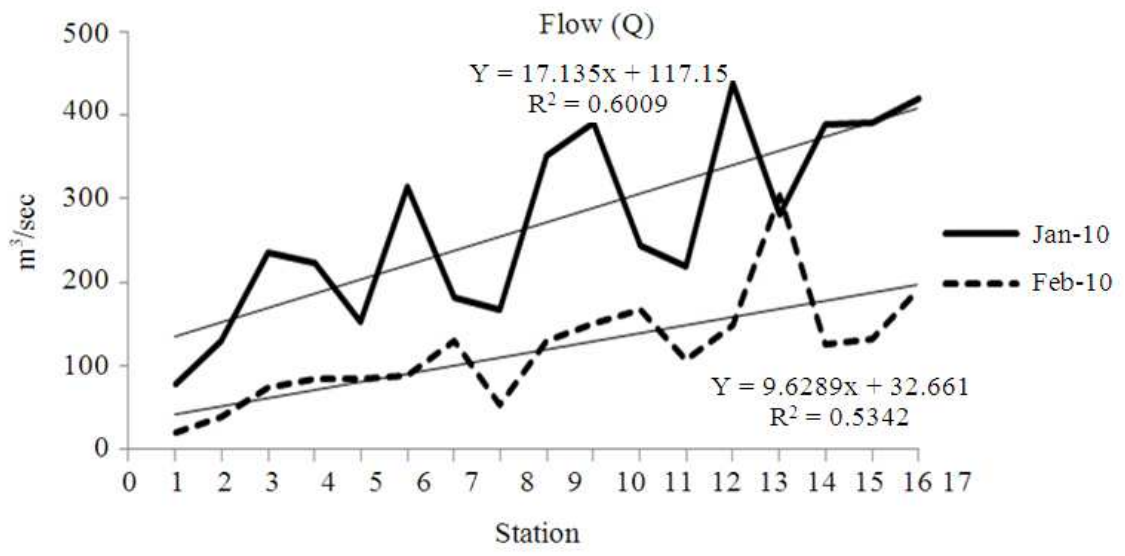

Fig. 4. The flows of 17 hydrologic stations for two sampling dates

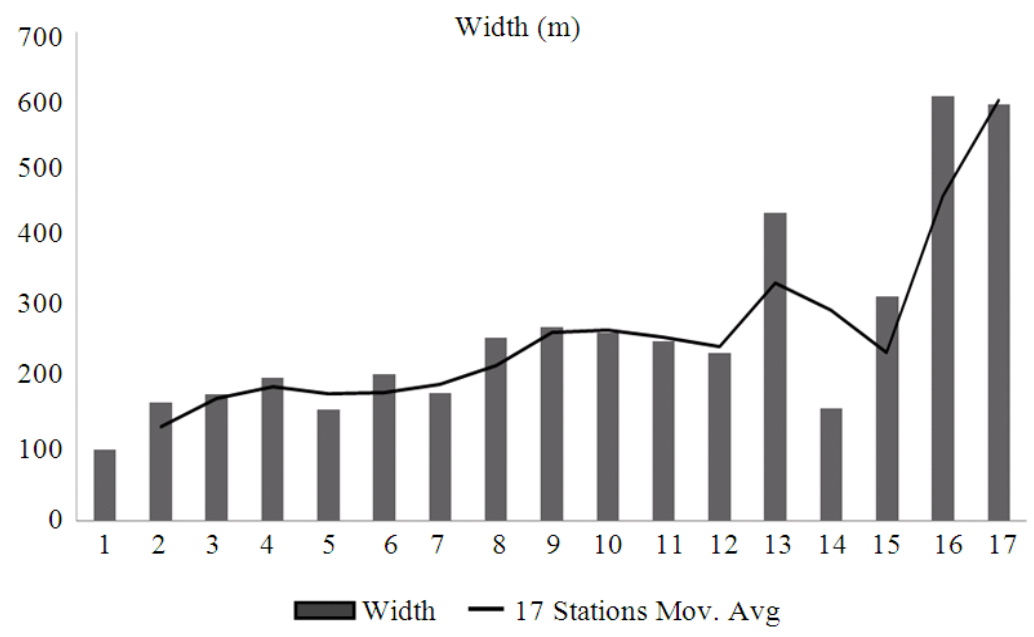

Fig. 5. The width of 17 hydrologic sampling stations of Pahang River

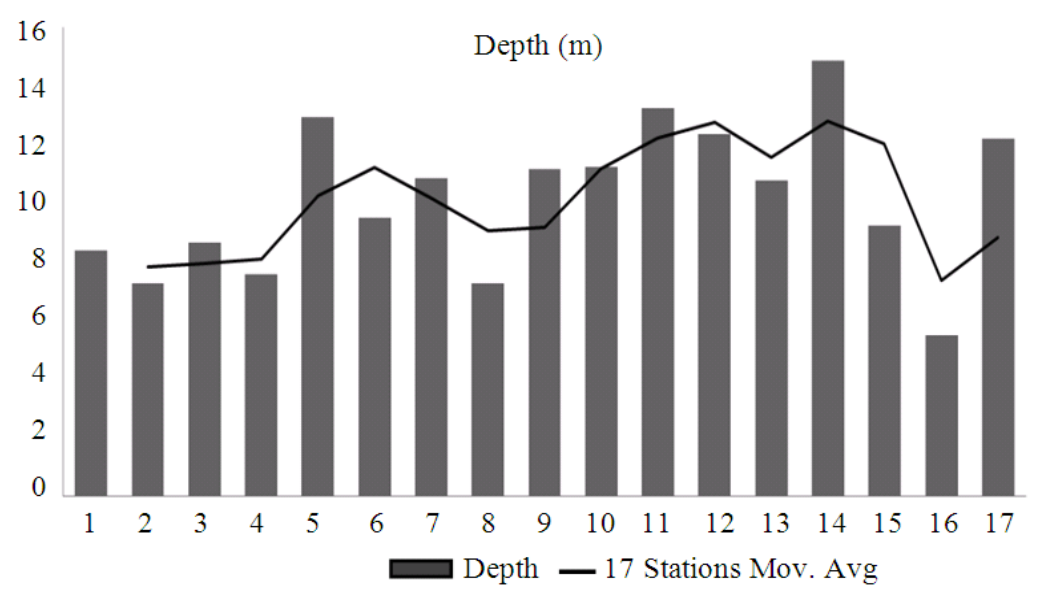

Fig. 6. The depth of 17 hydrologic sampling stations of Pahang River 
Muhamad Barzani Gasim et al. / American Journal of Applied Sciences, 10 (1): 42-57, 2013
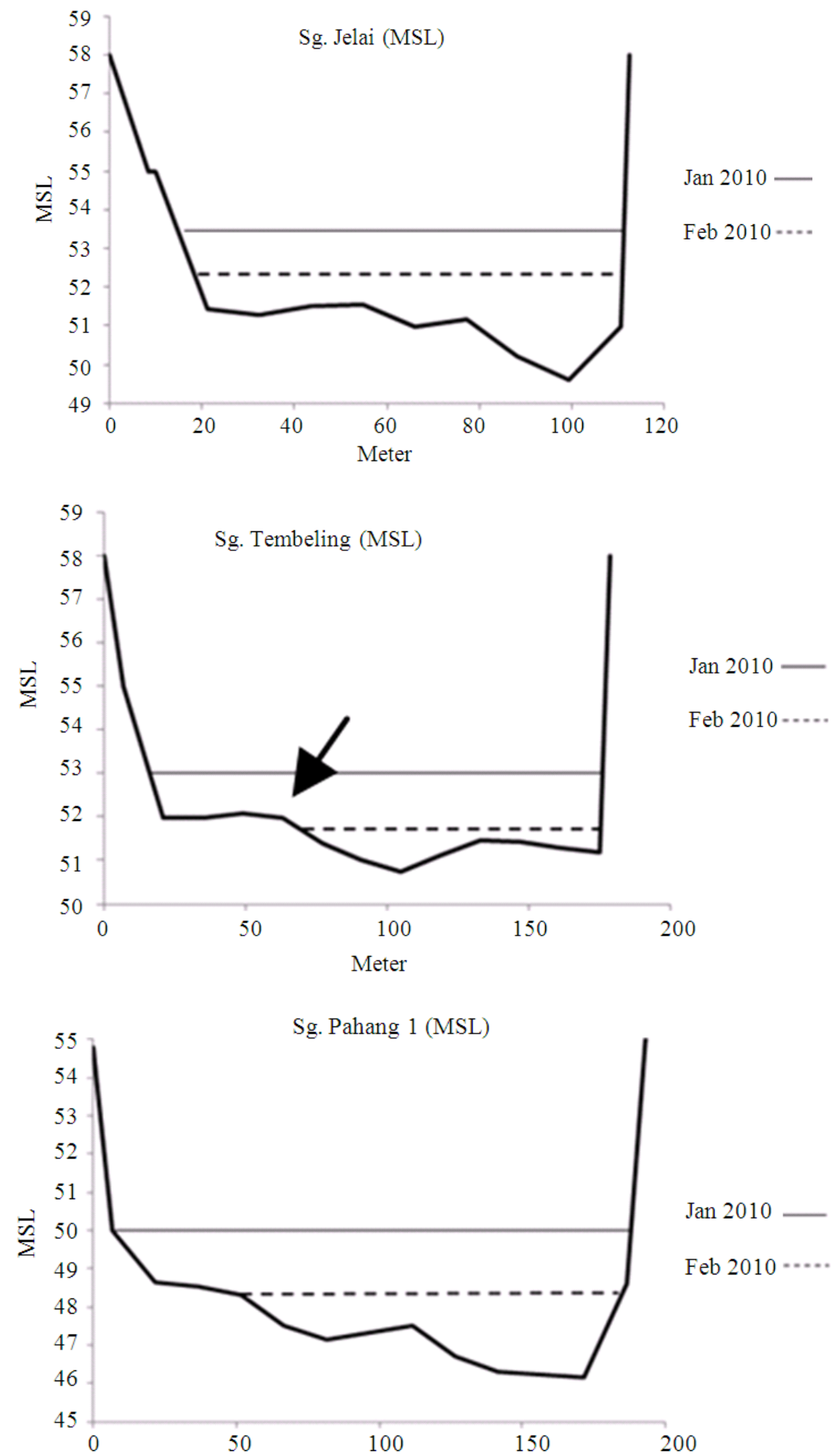
Muhamad Barzani Gasim et al. / American Journal of Applied Sciences, 10 (1): 42-57, 2013
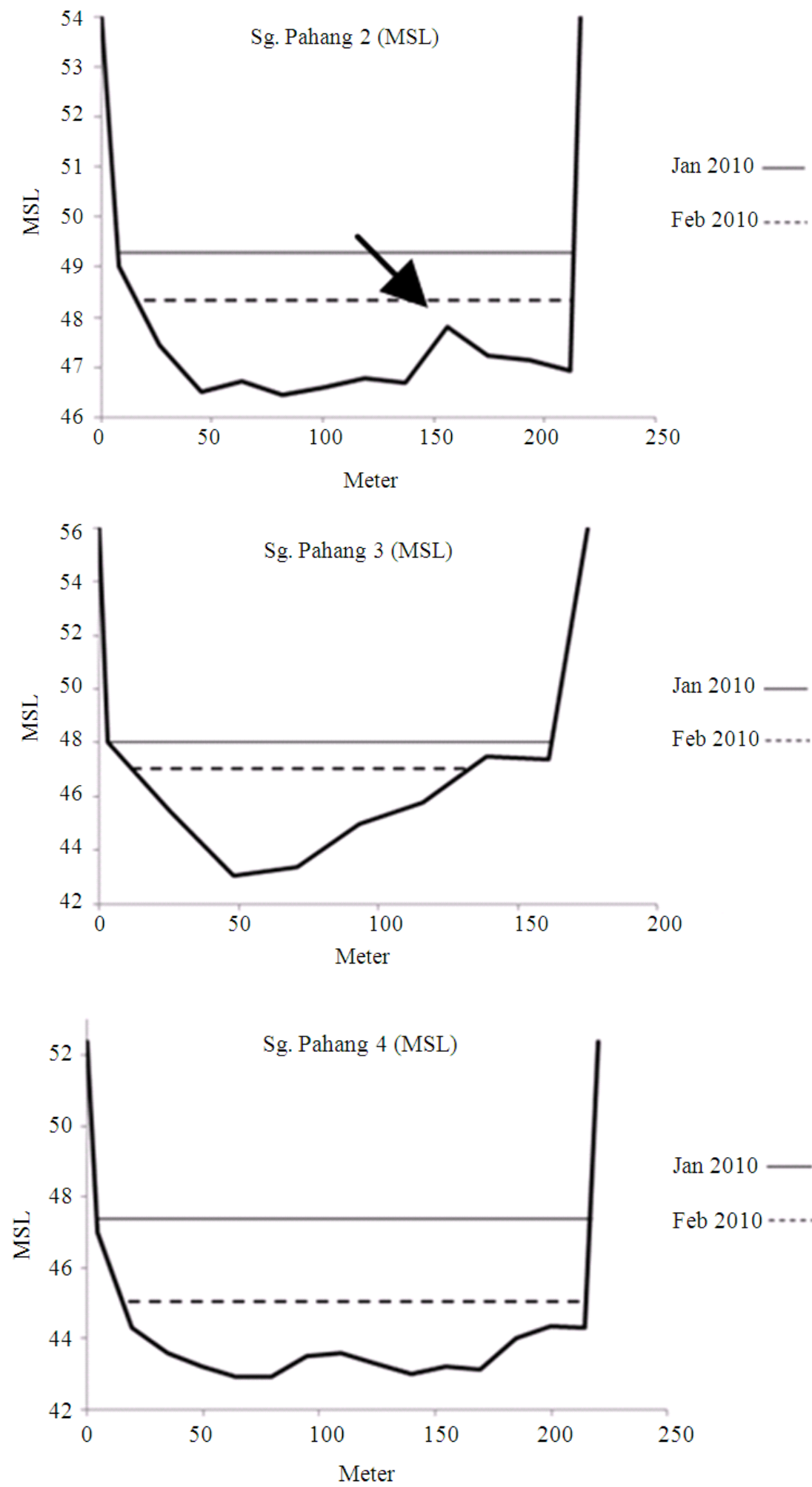

2010

Feb 2010 .....

Jan 2010

Feb $2010 \ldots$. 
Muhamad Barzani Gasim et al. / American Journal of Applied Sciences, 10 (1): 42-57, 2013
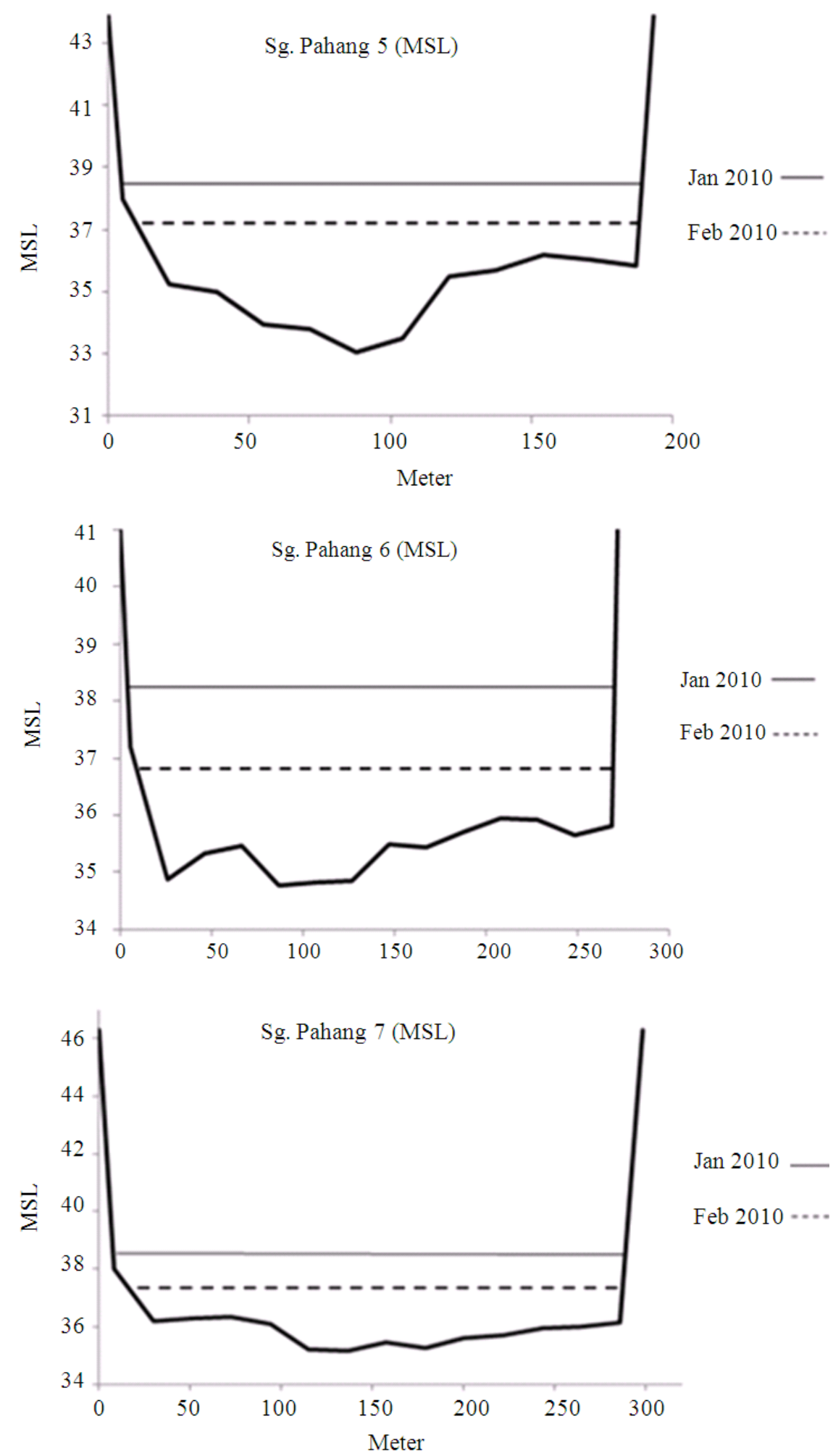

Jan 2010

Feb $2010 \ldots$ 
Muhamad Barzani Gasim et al. / American Journal of Applied Sciences, 10 (1): 42-57, 2013
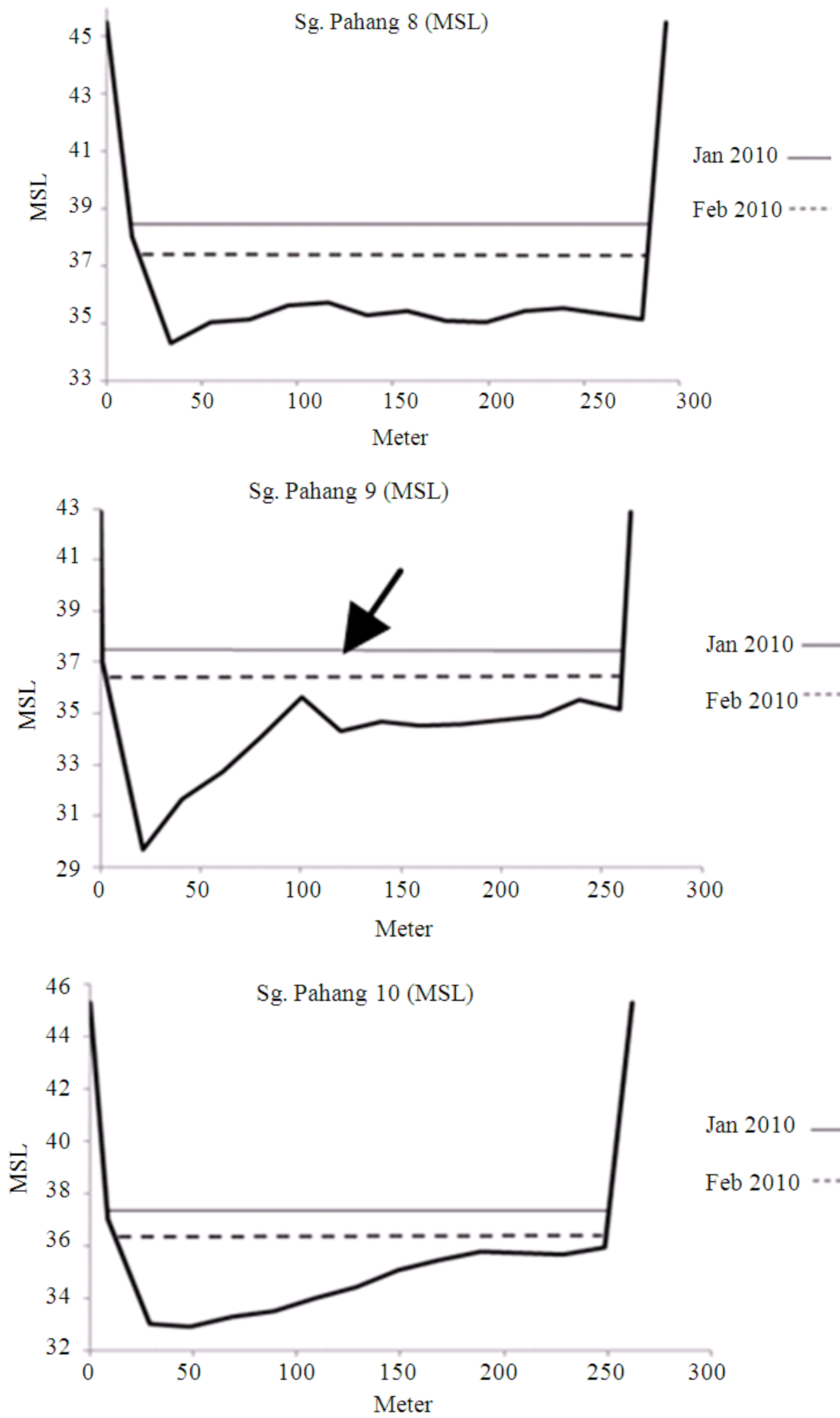
Muhamad Barzani Gasim et al. / American Journal of Applied Sciences, 10 (1): 42-57, 2013
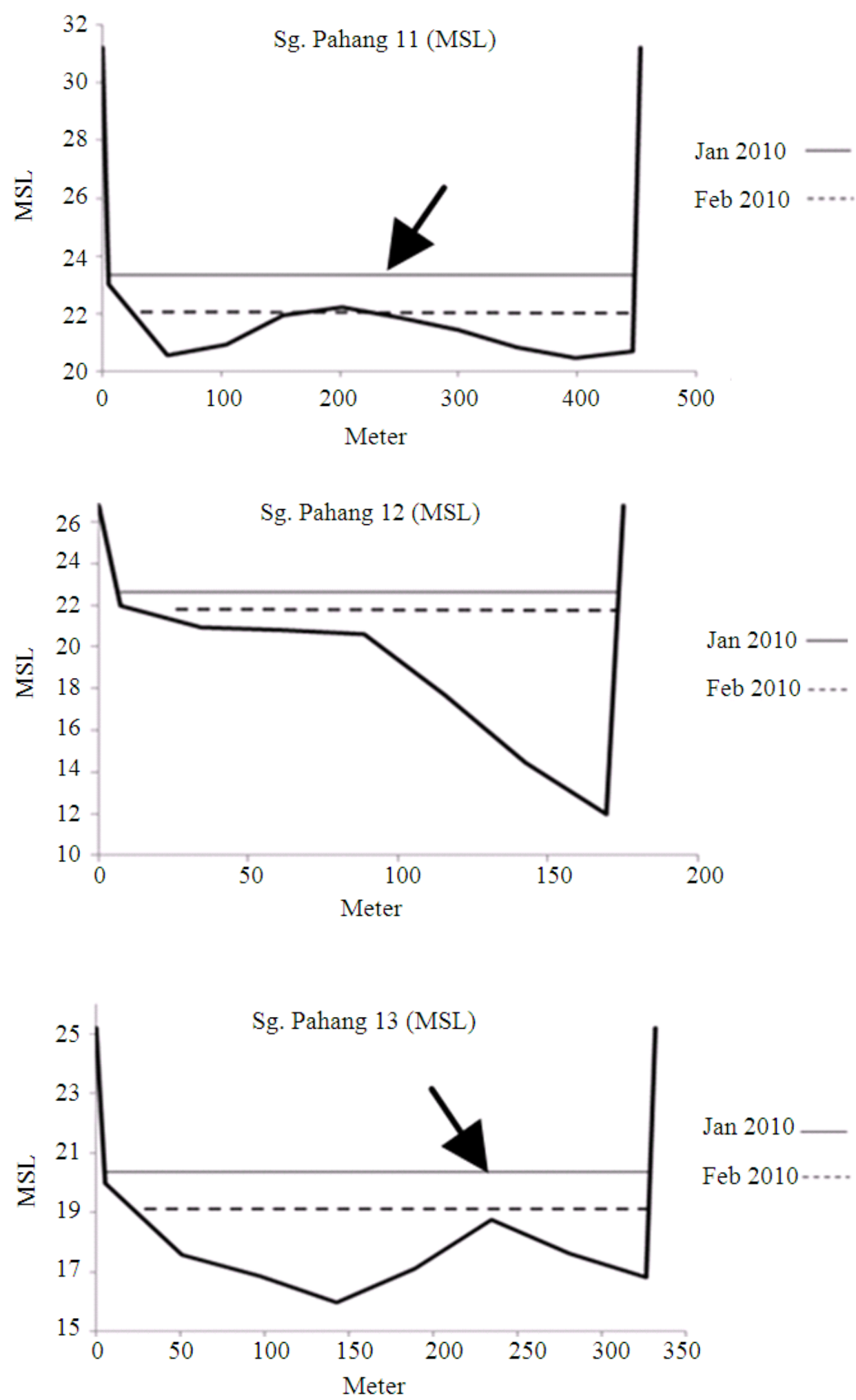
Muhamad Barzani Gasim et al. / American Journal of Applied Sciences, 10 (1): 42-57, 2013
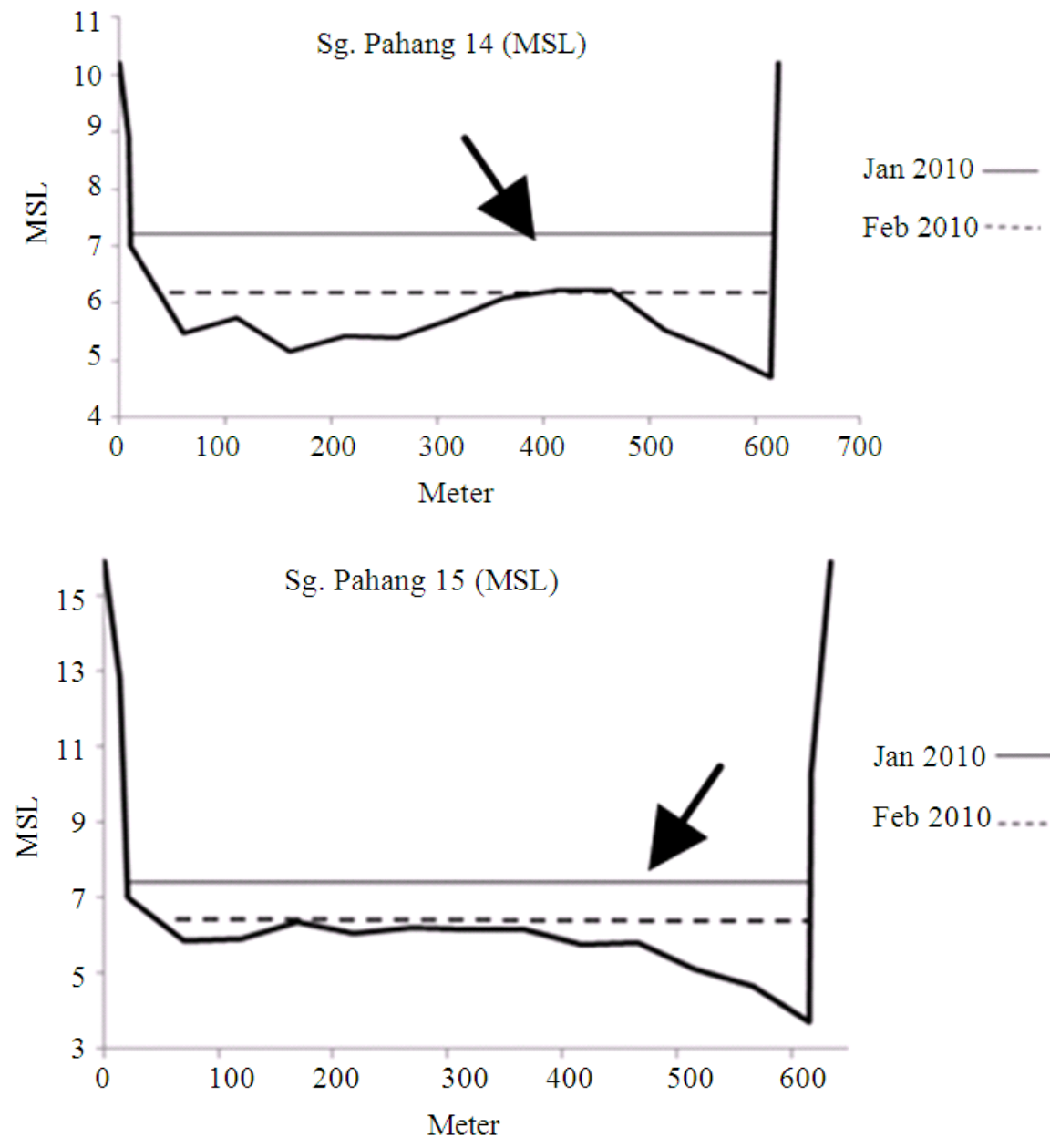

Jan $2010-$

Feb $2010 \ldots . .$.

Fig. 7. Cross-section and the water stage of 17 hydrologic sampling stations along the Pahang River and serious siltation (arrows)

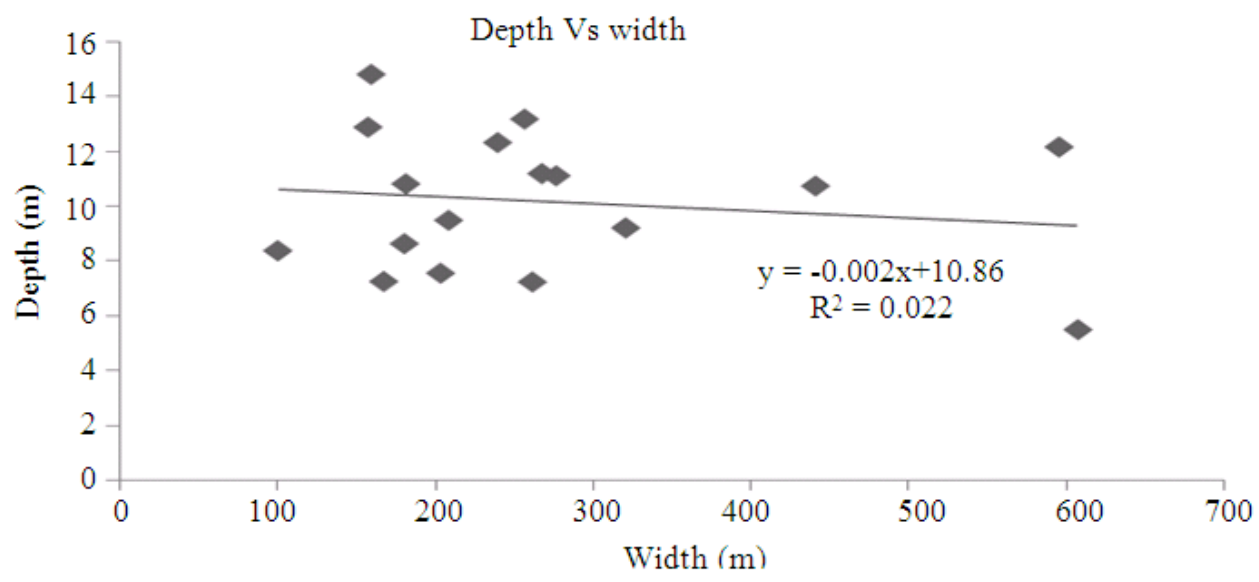

Fig. 8. The trend of depth versus width of pahang river 
Figure 7 shows the 17 river cross-sections and water stages of both hydrologic samplings which were carried out on January and February 2010. From these 17 hydrologic sampling stations; each station located at the estuary of Tembeling and Jelai Rivers and the rest (15 stations) up to the downstream. The water stages on January 2010 were ranged from 2.256 to $10.058 \mathrm{~m}$.

But decrease their water stage during second sampling (February) which was ranged from $0.956 \mathrm{~m}$ to $9.158 \mathrm{~m}$. The difference of water stage for 17 stations for both samplings was different from $0.9 \mathrm{~m}$ to $2.5 \mathrm{~m}$. Low of total rainfall due to dry season during second sampling has bearing to decreasing of water stage along Pahang River (Fig. 2). On February 2010, six stations i.e., station 1, 3, 11, 13, 14 and 15 not only experienced serious decreasing of water stages but the sandy river beds (arrows) were appeared with the accumulated sediments. Further decrease of water stages of the river would cause wider floodplain along the Pahang River during dry season. Through the river crosssectional profile (Fig. 7), it's assumed that river siltation has occurred along the Pahang River from upstream to downstream with its depositional sediments and these sediments tend to be accumulated at the middle of the river to form sand islands. The shallow of water stage had caused to the difficulty in boat transportation and fishery activity.

\section{DISCUSSION}

The influence of monsoon season in Peninsular Malaysia especially for Pahang River has two different meaning; flood and drought events. Atmospheric as well as oceanic factor has a dominant effect on the hydrological circle of the east coast part of the Peninsular. The result from 17 hydrologic sampling stations showed that the river depth and width of the Pahang River was inconsistent from upstream to downstream, these were caused a possessed meandering characteristic. Although long profile gradient of river normally decreases downstream and followed by increase of velocity due to increasing cross-section efficiency (hydraulic radius), this theory seems become not valid for Pahang River which experienced lower flow especially during dry season or drought season. The decreasing of velocity had resulted by lower flow of Pahang River due to dry season on February 2010.

Statistical analysis using linear model was applied to determine their correlation together with regression analysis. Four of the hydrologic parameters were selected to determine their correlation between two hydrologic samplings, January and February 2010. The relationship between depth and width of Pahang River showed no significant correlations, the correlations indicated that the R2 value was very weak (0.022) (Fig. 8).

The river flow, velocity, width and depth had been manipulated and plotted to compare each other and identified their relationships among these hydraulic parameters. The results had showed that, the flow-width trend for both sampling was increased (Fig. 9a and b). The increasing of river width when flowing downstream had resulted to the increasing of river flow. Besides that, the flow-depth trend of both sampling also displayed the increasing trend and showed that the increasing of river depth had also increased the river flow of Pahang River (Fig. 9c and d). On the other hand, the flow-velocity trend of first sampling had showed the increasing trend which indicated that the increasing of velocity had contributed to higher flow (Fig. 9e). But the trend of flow-velocity for second sampling (Fig. 9f) did not showed any increase or decrease of river flow when the river velocity was increased. This indicated that, the flow could be increased when the velocity is increased but that is not eligible for all weather especially for the hot season with minimal flow. The higher total rainfall during wet season (during monsoon season) has resulted to overflowing of Pahang River is an undeniable truth.

Human activities which have worsen the whole scenario with building of large area of impervious surface structures such as residential and urban areas have caused to the higher surface runoff during the raining season. The flash flood was occurred not only due to these impervious surface structures but the decreasing of forest lands in this Pahang River Basin which having least infiltration rate of water is the another factor that caused the higher flow of the Pahang River during this wet season.

However, human activity which involves development in the floodplain area is the primary cause to flood events (Hoyt and Langbein, 1955). The increasing demand of certain plantations in agriculture especially for oil palm and rubber plantations at this basin also contributed change of hydrodynamic function. Improper of land clearing in plantations have caused the higher surface runoff and sediments generated from the uncovered land (Lai et al., 1996) would be conveyed by surface runoff into drainage system nearby and caused to the decreasing drainage capacity of the river. 
Muhamad Barzani Gasim et al. / American Journal of Applied Sciences, 10 (1): 42-57, 2013

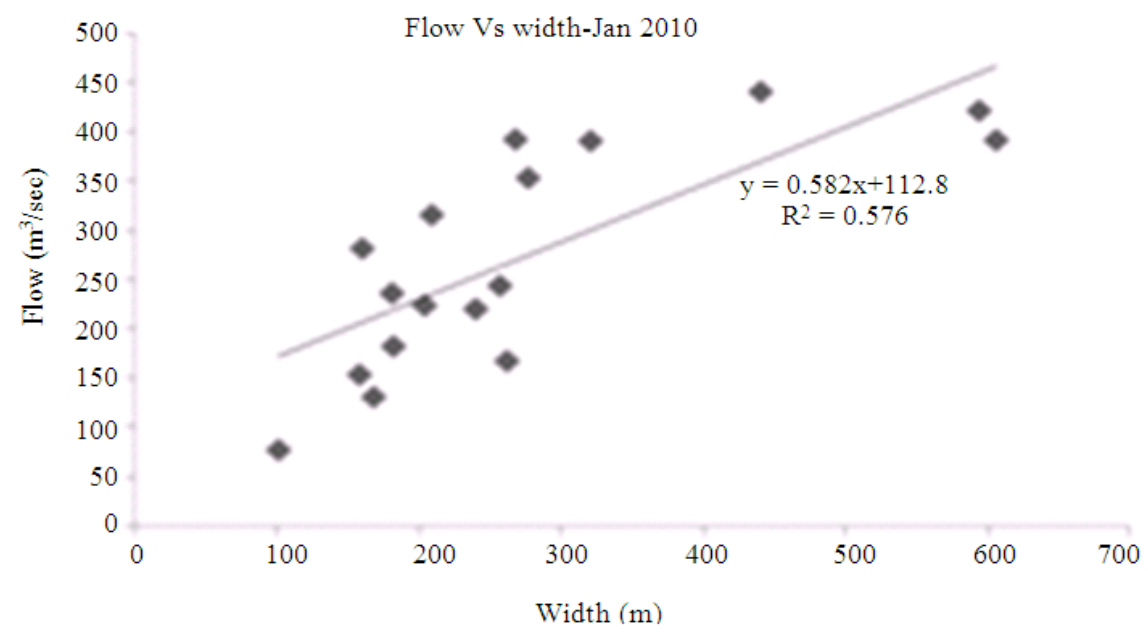

(a)

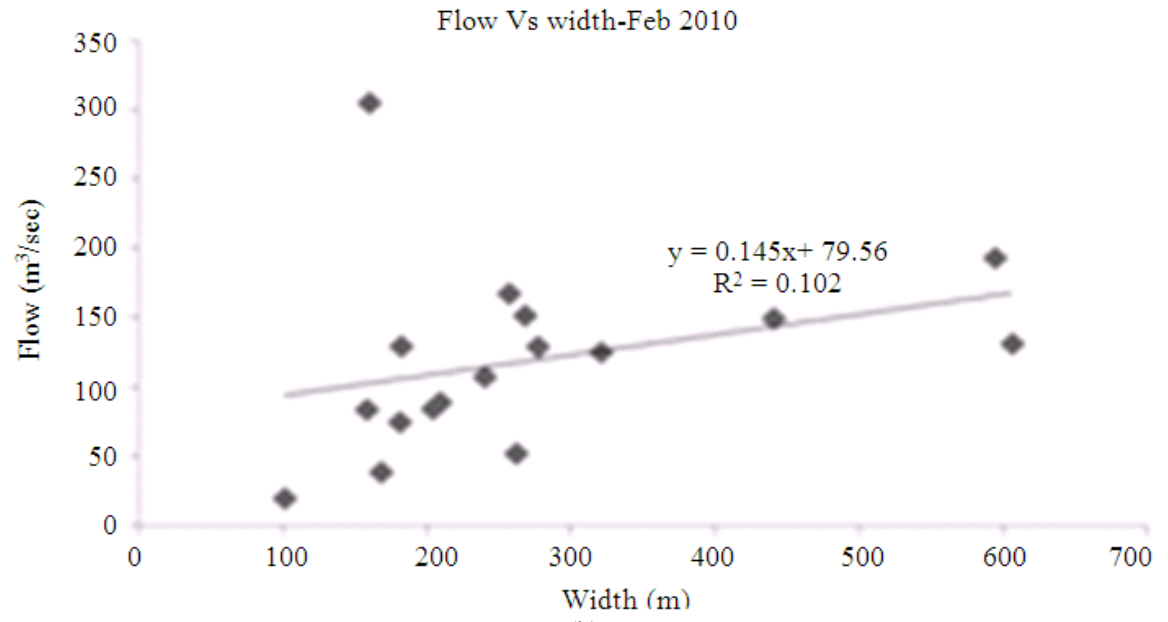

(b)

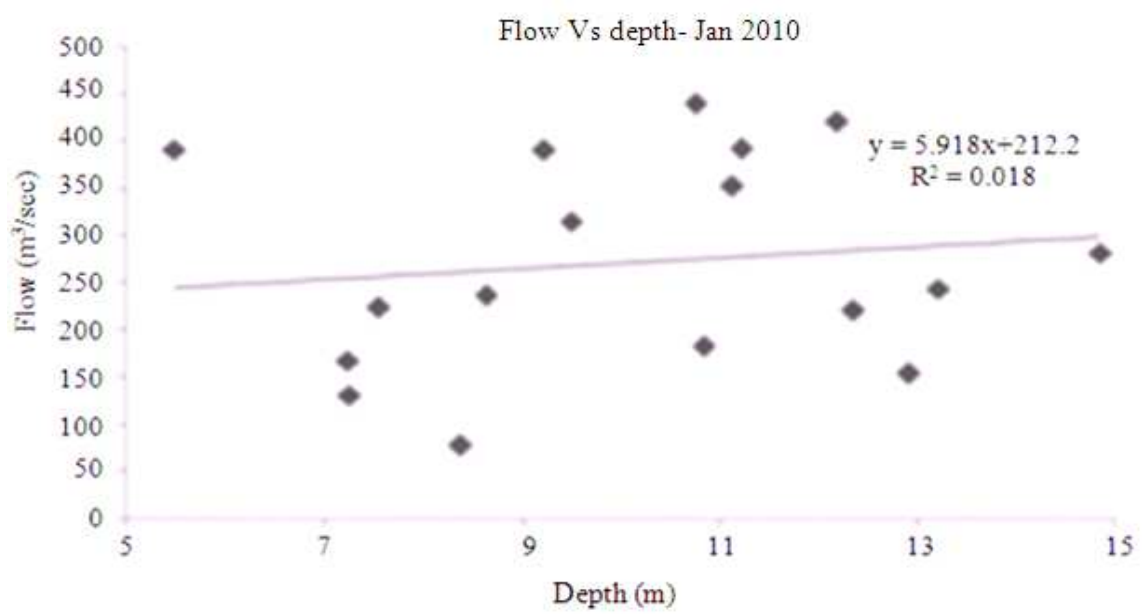

(c) 
Muhamad Barzani Gasim et al. / American Journal of Applied Sciences, 10 (1): 42-57, 2013

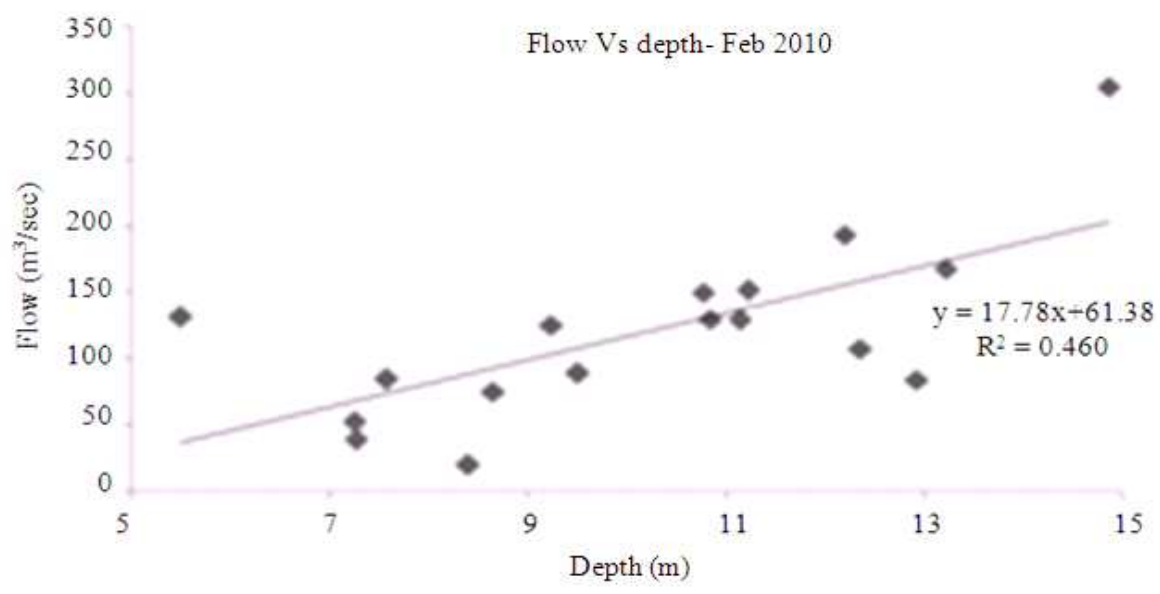

(d)

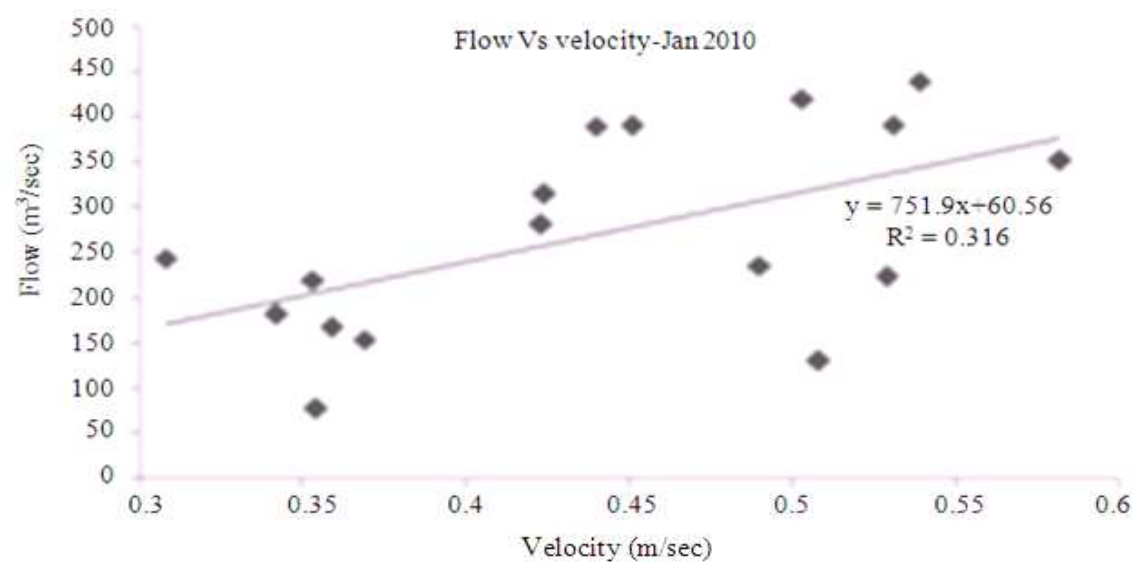

(e)

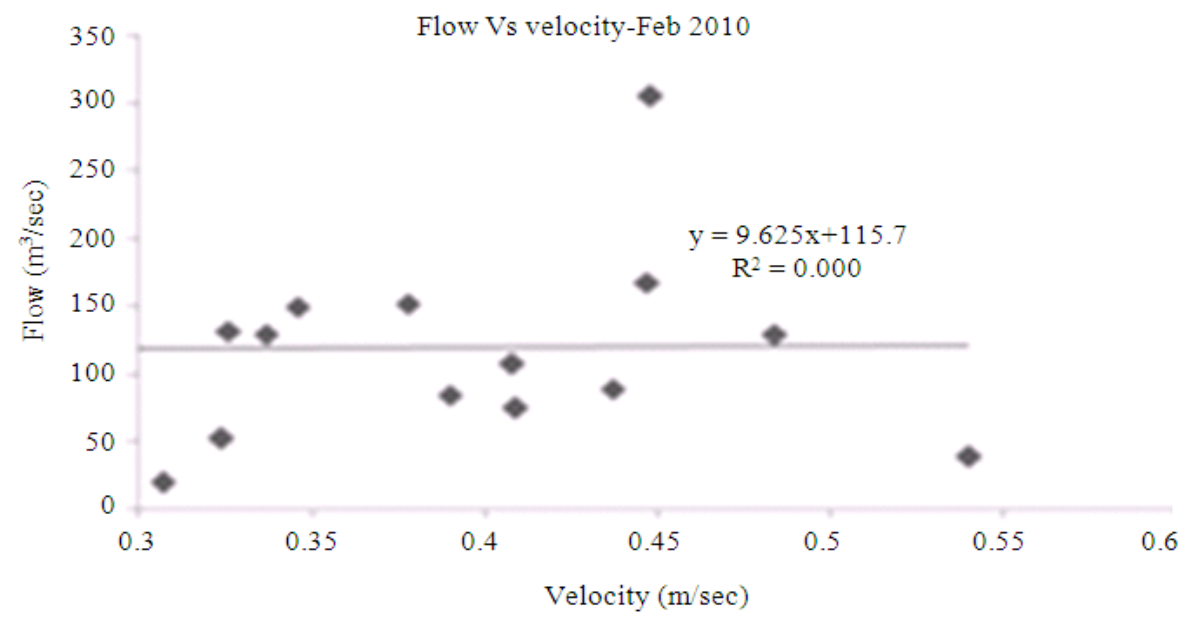

(f)

Fig. 9. The relationship between flow, velocity, width and depth of Pahang River (Source: DID Malaysia 2010) 


\section{CONCLUSION}

Pahang River had showed un-uniform of the river width and inconsistent of the river depth due to its meandering characteristic and showing sinuosity along its river course. The extreme weather especially the extreme rainfall had been identified as among the causes of extreme changes in hydrodynamic of Pahang River and had close relationship to major flood events along the Pahang River. Human activity is the undeniable cause to flooding events which involved of building of impervious structures and caused to the higher surface runoff and shorten the water delivery time to river nearby. On the other hand, plantation such as oil palm and rubber had resulted to high conveyance rate sediment into the tributaries and the Pahang River nearby and might cause to the decreasing size of drainage capacity of the Pahang River. Flood mitigations concept should be undertaken to minimize the impact of surface runoff directly to the river and another suggestion is to develop riparian zone along the Pahang River in order to minimize soil erosion as well as sedimentation enter to the river.

\section{ACKNOWLEDGMENT}

The researchers wish to acknowledge UKM for the grants under the UKM-GUP-ASPL-07-05-141 and UKM-OUP-P1-25-114/2010 projects respectively and the Minister of Higher Education for awarding the FRGS UKM-ST-06-FRGS115-2009. The authors would also like to express their appreciation to Faculty of Science and Technology, Universiti Kebangsaan Malaysia for the use of their research facilities.

\section{REFERENCES}

Allen, J.R.L., 1982. Sedimentary Structures, Their Character and Physical Basis. 1st Edn., Elsevier Science, New York, ISBN-10: 0444419454, pp: 633.

Andersson, L., J. Wilk, M.C. Todd, D.A. Hughes and A. Earle, 2006. Impact of climate change and development scenarios on flow patterns in the Okavango River. J. Hydrol., 331: 43-57. DOI: 10.1016/j.jhydrol.2006.04.039

Augusto, C.V., P.B. Marie, C. Stephane, R. Emmanuel and C.R.F. Otto et al., 2009. Hydrological monitoring of poorly gauged basins based on rainfall-runoff modeling and spatial altimetry. J. Hydrol., 379: 205-219. DOI: 10.1016/j.jhydrol.2009.09.049
Camporeale, C., P. Perona, A. Porporato and L. Ridolfi, 2007. Hierarchy of models for meandering rivers and related morphodynamic processes. Rev. Geophy. DOI: 10.1029/2005RG000185

Camporeale, C., P. Perona, A. Porporato and L. Ridolfi. 2005. On the long-term behavior of meandering rivers. Water Res. Res., 41: 1-13. DOI: 10.1029/2005WR004109

Chitale, S.V., 1970. River channel patterns. J. Hydraul. Div. Am. Soc. Civ. Eng., 96: 201-221.

Chow, V.T., D.R. Maidment and L.W. Mays, 1988. Applied Hydrology. 1st Edn., McGraw-Hill Education, New York, ISBN-10: 007070242X, pp: 572.

DID, 2005. Annual flooding report of nigeria pahang. DID, Malaysia.

DID, 2006. Annual flooding report of Pahang state 2006. DID, Malaysia.

DID, 2009. Annual flooding report of negeri pahang. DID, Malaysia.

Fu, C.B. and G. Wen, 1999. Variation of ecosystems over east asia in association with seasonal, interannual and decadal monsoon climate variability. Clim. Change, 43: 477-494. DOI: 10.1023/A:1005471600483

Howard, A.D., 1992. Modeling Channel Migration and Floodplain Sedimentation in Meandering Streams. In: Lowland Floodplain Rivers: Geomorphological Perspectives, Carling, P. and G.E. Petts (Eds.), John Wiley, Hoboken, NJ., ISBN-10: 0471931195, pp: 41-41.

Hoyle, J., A. Brooks and J. Spencer, 2012. Modelling reach-scale variability in sediment mobility: An approach for within-reach prioritization of river rehabilitation works. River Res. Appli., 28: 609-629. DOI: $10.1002 /$ rra. 1472

Hoyt, W.G. and W.B. Langbein, 1955. Floods. 3rd Edn., Princeton University Pres, New Jersey, pp: 469.

IPCC, 2001. The Scientific Basis: Contribution of Working Group I to the Second Assessment Report of the Intergovernmental Panel on Climate Change. 1st Edn., Cambridge University Press, New York.

Jaafar, O., M.E. Toriman, M. Idris, S.A.S. Mastura and H. Juahir et al., 2010b. Study of water leveldischarge relationship using Artificial Neural Network (ANN) in Sungai Gumum, Tasik Chini, Pahang, Malaysia. Res. J. Applied Sci., 5: 20-26. DOI: 10.3923/rjasci.2010.20.26

Jaafar, O., M.E. Toriman, S. Mastura S.A.M.B. Gazim and P.I. Lan et al., 2010a. Modeling the impacts of ringlet reservoir on downstream hydraulic capacity of Bertam River using XPSWMM in cameron highlands, Malaysia. Res. J. Applied Sci., 5: 47-53. DOI: $10.3923 /$ rjasci.2010.47.53 
John, A.Y., 1987. Physics of Monsoons: The Current View. In: Monsoons, Fein, J.S. and P.L. Stephens (Eds.), John Wiley and Sons, New York, ISBN-10: 0471874167, pp: 211-243.

Jung, I.W., H. Chang and H. Moradkhani. 2011. Quantifying uncertainty in urban flooding analysis considering hydro-climatic projection and urban development effects. Hydrol. Earth Syst. Sci., 15: 617-633. DOI: 10.5194/hess-15-617-2011

Kale, V.S. and P.S. Hire, 2004. Effectiveness of monsoon floods on the Tapi River, India: Role of channel geometry and hydrologic regime. Geomorphology, 57: 275-291. DOI: 10.1016/S0169$555 \mathrm{X}(03) 00107-7$

Kamarudin, M.K.A., M.E. Toriman, S. Mastura, M. Idris and N.R. Jamil, 2009. Temporal variability on lowland river sediment properties and yield. Am. J. Environ. Sci., 5: 657-663. DOI: 10.3844/ajessp.2009.657.663

Lai, F.S., J.S. Ahmad and M.A. Zaki, 1996. Sediment yields from selected catchments in Peninsular Malaysia. Proceedings of the Exeter Symposium, Erosion and Sediment Yield: Global and Regional Perspectives. (ESESYGRP' 96), IAHS-AISH Publication, pp: 223-231.

Leopold, L.H., 1953. Downstream change of velocity in rivers. Am. J. Sci., 25: 606-624.

Lun, P.I., M.B. Gasim, M.E. Toriman and K.A. Kamarudin, 2010. River flow conditions and dynamic state of Pahang River. Proceedings of the 3rd Indonesia-Malaysia Joint Conference, Oct. 6-8, Universitas Pembangunan Sosial Yogyakarta, Indonesia, pp: 24-25.

Lun, P.I., M.B. Gasim, M.E. Toriman, S.A. Rahim and K.A. Kamarudin, 2011. Hydrological pattern of pahang river basin and their relation to flood historical event. J. e-Bangi, 6: 29-37.

Pal, I. and A. Al-Tabbaa, 2010. Regional Changes in extreme monsoon rainfall deficit and excess in India. Dynamics Atmosphere Oceans, 49: 206-214. DOI: $10.1016 /$ j.dynatmoce.2009.07.001
Schwendel, A.C., I.C. Fuller and R.G. Death, 2012. Assessing DEM interpolation methods for effective representation of upland stream morphology for rapid appraisal of bed stability. River Res. Appli., 28: 567-584. DOI: 10.1002/rra.1475

Suhaila, J., S. Deni, W.W. Zin and A. Jemain, 2010. Spatial patterns and trends of daily rainfall regime in Peninsular Malaysia during the southwest and northeast monsoons: 1975-2004. Meteorol. Atmospheric Physics, 110: 1-18. DOI: 10.1007/s00703-010-0108-6

Toriman, M.E., M.B. Gasim, Z. Yusop, I. Shahid and S.A.S. Mastura et al., 2012. Use of ${ }^{137}$ Cs activity to investigate sediment movement and transport modeling in river coastal environment. Am. J. Environ. Sci., 8: 417-423. DOI: 10.3844/ajessp.2012.417.423

Vorosmarty, C., C. Birkett, L. Dingman, D.P. Lettenmaier and Y. Kim et al., 1999. NASA Post2002 land surface hydrology mission component for surface water monitoring. Proceedings of the HYDRA_SAT, A Report from the NASA Post 2002 LSHP Planning Workshop, Apr. 12-14, Irvine CA.

Wallis, C., I. Maddock, F. Visser and M. Acreman, 2012. A framework for evaluating the spatial configuration and temporal dynamics of hydraulic patches. River Res. Appli., 28: 585-593. DOI: 10.1002/rra.1468

Walter, C. and D.D. Tullos, 2010. Downstream channel changes after a small dam removal: Using aerial photos and measurement error for context; Calapooia River, Oregon. River Res. Appli., 26: 1220-1245. DOI: 10.1002/rra.1323

Yan, O.C., 1987. Hydrological Procedure No.4Magnitude and frequency of floods in Peninsular Malaysia (Revised and updated). DID, Malaysia.

Zin, W.Z.W. and A.A. Jemain, 2010. Statistical distributions of extreme dry spell in Peninsular Malaysia. Theoretical Applied Climatol. DOI: 10.1007/s00704-010-0254-2 